\title{
Subcontractor Contact
}

National Cancer Institute

\section{Source}

National Cancer Institute. Subcontractor Contact. NCI Thesaurus. Code C127534.

The main or principle contact person for a subcontractor or subcontracting org anization. 